\title{
TYPES OF THE ENTERPRISE FINANCIAL POLICY IN THE PROCESS OF ITS IMPLEMENTATION
}

\author{
Iryna Kreidych ${ }^{1}$ \\ kreidichin@gmail.com
}

Julia Yereshko'

julia.jereshko@gmail.com

Vahan Tovmasian

Private Higher Educational Institution "European University"

16-B Academika Vernadskogo blvd., Kyiv, Ukraine, 02000

tvrscience@gmail.com

${ }^{1}$ National Technical University of Ukraine "Igor Sikorsky Kyiv Polytechnic Institute" 32 Peremohy ave., Kyiv, Ukraine, 03056

\begin{abstract}
The current research conducts the study of the enterprise financial policy in an aspect of formalising its types in an attempt to maximize its efficiency and practical sense as the latter are basically absent due to lacking proper scientific background. That is, subsystems of financial policy are perceived by domestic scholars as its types, which make it impossible to create a rational, functioning and effective managerial system.

Arranging the enterprise financial policy to specific types allows easier achievement of a chosen strategy and formulated objectives as each such type is a set of methods, levers and tools for making and implementing management decisions, which provides optimisation to this process, thus achieving the maximum efficiency of financial management

The analysis of domestic scientific achievements on the researched problems, or rather total lack of such, proved the necessity to substantiate the types of enterprise financial policy. Thus, the subsystems of financial policy: depreciation, tax, dividend and others are perceived by domestic scholars as its types, which lead to an erroneous understanding of its essence and process mechanism of its implementation, and hence - the controversial scientific and practical value of existing research.

The given research proposes following types of the enterprise financial policy: stabilizing financial policy, proliferative financial policy, innovative financial policy and urgent financial policy, that are meant to be used in specific economic conditions and in accordance with current managerial objectives and maximize the effectiveness of financial management.

Keywords: enterprise financial policy, stabilizing financial policy, proliferative financial policy, innovative financial policy, urgent financial policy, anti-crisis management, financial management.
\end{abstract}

DOI: $10.21303 / 2504-5571.2020 .001442$

\section{Introduction}

Policy is the cornerstone of management efficiency, since, in fact, it is its objective basis. The managerial function of the enterprise financial policy is manifested in an implementation of financial management as a continuous cyclical process, through the development of strategies and tactics, policy goals, solutions and alternatives, tools, methods and levers for its implementation, etc., and, in particular, the formation of the financial mechanism of the enterprise within the limits of its (policy) implementation. Management as a process cannot be an elementary set of stochastic, episodic actions, unconnected in space and time, as well as contain informational and functional lags, since in essence it is an influence that transforms the system that is its object.

Therefore, the proper functioning of this system is directly mediated by the presence of a clear guide to action, in other words, an algorithm with a "scenario" (or a set of alternatives) with an unconditional distribution of: responsibilities and powers; executors of all stages of the process; resources and tools. Thus, the basis for this function is the development of a specific set of solutions and alternatives, which allows the simultaneous implementation of managerial influence in terms of achieving goals and provides built-in control over the activities of the structural elements of the enterprise in a certain system orientation - i. e., a particular type of policy. 
The correct choice of the financial policy type allows the formation of a clear guide to action and simplifies the implementation process in terms of having a clear ready-made set of measures and the corresponding tools.

Unfortunately, Ukrainian [1-3] and foreign [4-8] scientific thought lacks meaningful framework of such kind.

Aim of research is to substantiate types of the enterprise financial policy in an attempt to create an effective decision-making mechanism.

\section{Methods}

The theoretical and methodological basis of the study is a system of general scientific and special methods of cognition, namely: comparison (was used to retrospectively substantiate the lack of meaningful research and therefore to emphasize the need in such), synthesis (was used to group managerial decisions in order to form given types of financial policy), prediction and projection (were used combined to affiliate the appropriate choice in a financial policy type with the effectiveness of managerial decision-making), etc.

\section{Research results}

Choosing the appropriate type of policy. The implementation of the financial policy of the enterprise begins with a thorough financial and economic analysis of the enterprise, based on which the tasks of financial policy are determined in accordance with the company's mission, strategy (s), goals and objectives of financial management; choosing the appropriate type of policy and tools and levers to influence the elements of the system.

Depending on the chosen strategy and formulated objectives of financial policy, we propose to choose one of the following types, each of which is a set of methods and levers for making and implementing management decisions, which allows automation of this process, thus achieving the maximum efficiency of financial management:

1. Stabilizing financial policy is used to achieve and maintain the entity's financial balance entity in different economic conditions by adjusting the level of its business activity, essentially representing the mitigation of cyclicality in the short term and is to optimize the company's cash flows.

Desynchronization and imbalance of the company's cash flows forms the basis for the following risks emergence: insolvency and loss of absolute liquidity; lengthening the enterprise's operating and financial cycles; missed opportunities for profit, as well as an increase in the level of losses due to the diversion of highly liquid assets in order to eliminate the above factors; a general threat to the economic security of an economic entity due to the need to use insurance and reserve funds for the rapid current elimination of the abovementioned risks. Therefore, the achievement and maintenance of financial stability by the enterprise is ensured through the optimization of its cash flows, which solves the problem of minimizing and/or levelling the threats, described above.

Among the contemporary domestic scientific heritage, the most meaningful, in our opinion, is the model of the enterprise cash flows optimization, described in [9], which consists in their synchronization, balancing and targeting of the net cash flow in accordance with the minimum required insurance balance of cash, which resolves the tasks of stabilizing financial policy. Thus, in [9], the author had illustrated the representation of the business cycle of an enterprise by a graphical expression of its net cash flow function, which makes it possible to make an assumption about the effectiveness of applying a generally known methodology of countercyclical policy to it. Thus, depending on the behaviour of the net cash flow and the tasks of stabilization, that is, stimulation, or containment, the financial management of the enterprise uses:

1. 1. Expansionary (from the Latin expānsio - to increase) financial policy - in order to eliminate the deficient cash flow, characterized by lack of cash, and hence - the need to find internal and external sources of funding. Such financial policy measures include [9, p. 164-166]:

- rationalizing the management of accounts receivable in terms of optimizing its volumes in accordance with the turnover of a given asset, as well as its assignment in order to accelerate the operational and, accordingly, the financial cycle of the enterprise (factoring); 
- search for internal reserves of funds: lease of fixed assets and/or sale of unused ones; conducting marketing activities and improving pricing and product policies, aimed at increasing the volume of product sales; refusal to provide a certain type of discounts or modification of the policy for their provision;

- sale of part or all of the investment instruments or short-term investment of temporarily free funds in order to obtain additional profit;

- acceleration of payment turnover;

- reducing the amount of the outgoing cash flow by: reducing the level of operating costs; tax policy optimization; reduction and restructuring of financial and real investments; use of leasing; debt restructuring; temporary reduction or refusal to pay dividends, etc.

1. 2. Recessionary (from the Latin recido - to decline, shrink) financial policy, which consists in the maximum possible avoidance of irrational use of funds by eliminating their surplus and can be implemented by the following measures [9, p. 164-166]:

- expansion of volumes and directions of the investment policy using the surplus funds in order to increase the size of real and financial investments, self-investment; accelerating the implementation of investment projects; financing the expansion and/or renewal of production;

- early liabilities repayment;

- advance payment of dividends;

- conducting aggressive marketing and pricing policies;

- expansion of the assortment policy, development and introduction of new products and/ or new production line, new technologies; development of new markets, creation of branches, etc.;

- placing superfluous funds on deposits, purchasing highly liquid securities, etc.;

- expansion of the company's investment portfolio, etc.

With any kind of stabilization policy, required at this stage, budgeting is the main implementation tool, it allows a competent assessment of the company's cash flows and their comprehensive management through a system of financial plans and acts as the basis for the development of algorithms for making managerial decisions in specific economic circumstances and conditions.

2. Innovative financial policy is used to achieve the maximum efficiency in financing the company's innovative activities while maintaining the normal rhythm of its economic activity as much as possible. The essence and functional features of financial policy, mentioned by us previously in [10], are manifested in the complexity of management measures in the process of achieving the planned result, namely: avoiding risks and threats to economic security of the business entity on the way to the goal. Aspect features of the management process as a "policy" create the prerequisites for the implementation of financial management on the basis of "ratio" rather than "maxime". So, the main task that is to be solved with the use of financial policy as a management basis is that the object of the political process is guaranteed not to undergo significant financial and economic fluctuations in the long run in the pursuit of achieving a rapid innovative effect.

In fact, the main function of the innovative financial policy is active financing of innovations with the elimination of a fairly common scenario today: an economic entity suffers colossal financial losses, or even finds itself on the verge of bankruptcy as a result of channelling the lion's share of financial resources and economic factors and/or:

- protracted innovation process for various objective and subjective reasons;

- time and financial lags in innovation and investment activities;

- unfair competition policy of other market players, industrial espionage, fierce competition in the market;

- failure of a marketing strategy, failure to achieve the desired market response;

- a failed course of innovation;

- slow "innovative" reaction, etc.

The list of the most high-profile bankruptcies and exits of companies from the market as a result of the factors, described above or their combinations, are given in Table $\mathbf{1 .}$

Hence, we can conclude that the size, experience, brand awareness, high-tech (some of the companies, mentioned in Table 1, were considered to be innovation leaders), the value of the company and its market position, even diversification, do not guarantee the elimination of economic 
threats up to bankruptcy as a result of controversial management decisions in the field of implementation and financing of innovations. So, some companies, listed above, were too "heavy" to respond quickly to changes in consumer sentiment and needs, some on the contrary - too confidently actively "innovated", which resulted in the same expected effect - some companies changed owners, some were forced to resort to mergers, re-profiling (sometimes radical), and the rest, unfortunately, have become history.

Table 1

Famous threats to the economic security of companies due to contradictory innovation (built by authors on the basis of [11-14])

\begin{tabular}{|c|c|c|c|c|}
\hline Name & $\begin{array}{c}\text { Year of } \\
\text { establishment }\end{array}$ & Peak valuation & $\begin{array}{l}\text { Year of legal entity } \\
\text { termination/ } \\
\text { bankruptcy }\end{array}$ & Cause \\
\hline KODAK & 1881 & $\$ 31$ billion & 2012 & $\begin{array}{l}\text { Failure to define a new niche; lack of strategic } \\
\text { creativity; lack of organizational skills, lack of } \\
\text { financial opportunities for the innovation process } \\
\text { as a consequence }\end{array}$ \\
\hline Nokia & 1865 (1997) & $\$ 300$ billion & 2013 & $\begin{array}{l}\text { Failed operating system development; lack of } \\
\text { timely response to consumer needs; loss of } \\
\text { financial liquidity as a result; impossibility of } \\
\text { financing further innovations }\end{array}$ \\
\hline IBM & 1888 & $\$ 32$ billion & $\begin{array}{l}1999 \text { (filed for bank- } \\
\text { ruptcy), } 2010 \text { (on the } \\
\text { verge of bankruptcy) }\end{array}$ & $\begin{array}{c}\text { Failed "strategic imperatives" of the company; } \\
\text { unpaid infestations in cloud computing technol- } \\
\text { ogy and business services, based on artificial } \\
\text { intelligence Watson }\end{array}$ \\
\hline Blockbuster & 1985 & $\$ 8.4$ billion & 2010 & $\begin{array}{l}\text { Lack of timely response to changing needs; } \\
\text { rejection of innovations; belated innovations }\end{array}$ \\
\hline Vertu & 1998 & \$ 297 million & 2017 & $\begin{array}{l}\text { Slow implementation of innovations; lack of } \\
\text { response to consumer needs; loss of liquidity }\end{array}$ \\
\hline $\begin{array}{l}\text { Hummer (brand) and } \\
\text { General Motors }\end{array}$ & 1979 (1908) & $\$ 262$ billion & 2010 & $\begin{array}{l}\text { Detroit Crisis; insufficient market flexibility; } \\
\text { failed innovative financial policy }\end{array}$ \\
\hline Enron & 1985 & $\$ 101$ billion & 2001 & $\begin{array}{c}\text { Dotcom crisis; failed financial policy in the field } \\
\text { of investment and innovation; inconsistency of } \\
\text { the voiced level of innovation with the actual } \\
\text { implementation }\end{array}$ \\
\hline Toshiba & 1875 (1939) & $\begin{array}{l}3.3 \text { trillion yen } \\
(\$ 3.2 \text { billion })\end{array}$ & 2017 & $\begin{array}{l}\text { Controversial financial and accounting policies } \\
\text { that caused a } \$ 1.2 \text { billion net loss in } 2015 \text { and } \\
\text { failed to respond in a timely manner to finan- } \\
\text { cial losses from a related nuclear program: the } \\
\text { company lost more than } \$ 9 \text { billion due to a } \\
\text { failed nuclear reactor design by its subsidiary } \\
\text { Westinghouse }\end{array}$ \\
\hline
\end{tabular}

The main functional tasks and measures of innovative financial policy include:

- prompt response to changing needs in financing innovation;

- building an optimal model for financing innovation, taking into account the stage of the business cycle of the enterprise, the general market situation and public sentiment;

- constant monitoring of the market with an appropriate process response to the alternation of measures and objectives of financial policy;

- optimization of accounting policies;

- automation of management decisions;

- qualitative substantiation of the investment attraction policy; 
- creation of reserve funds and reserve alternative financial plans;

- self-financing and self-investment;

- attraction of external investments; sale of securities and the like; the use of combinations of financial instruments, etc.

3. Proliferative financial policy the policy is used in order to optimally direct the total financial resources and economic factors in order to quickly capture the market, oust/absorb competitors; as well as active brand promotion, aggressive marketing policy, etc. By its nature, it is a radicalized form of expansionary stabilization financial policy of the enterprise. The main difference between them is the scale and purpose, because the latter aims to eliminate the excess cash flow in order to avoid possible irrational stocks of "dead cash". Proliferative financial policy should be used in a consistent combination with stabilizing one, it can also be a logical link in the system: innovative proliferative - stabilizing policy, depending on the cornerstone needs of the business entity and the current tasks of financial management.

4. As an anti-crisis one can use both stabilizing and urgent financial policies, depending on the scale and suddenness of threats to the economic security of the enterprise. Urgent financial policy, in our opinion, is a key in the need to respond immediately to sudden and/or critical economic threats and force majeure, facing the company. Thus, world economic history is evidence of a number of global threats, sometimes in no way expected, with unpredictable consequences and duration. The latest example of such a threat is the ongoing "corona crisis", caused by the COVID-19 pandemic, which has more or less affected all sectors of the economy and continues to this day. Even at the current level of development of productive forces there is no possibility of a reliable adequate assessment of the consequences of this phenomenon, its duration and time of remission, as well as the period of rehabilitation of the world economy.

For example, the aviation industry has suffered perhaps the greatest economic consequences as a result of the "corona crisis". Thus, as of September 14, 2020, EUROCONTROL has reduced the forecast for the resumption of air traffic to $45 \%$ of its volume in the European aviation area in 2019, which means an increase in projected total losses for the industry in 140 billion euros [15]. This crisis, as well as its time and economic scale, turned out to be unexpected for the industry, as well as for the rest of the World. Domestic aviation suffered the same blow ("in the last weeks of March and throughout April the number of flights in the airspace of Ukraine decreased by more than $95 \%$ ") against the background of "the loss of several airports, air navigation infrastructure, a sharp decrease in passenger traffic and transit flights in the air space of Ukraine", caused by the annexation of Crimea and hostilities in CADLO [16].

As a result, the strategic state monopoly UkSATSE found itself in unprecedented conditions. The management of the enterprise, in order to ensure its smooth operation, resorted to the introduction of a number of anti-crisis measures, in particular, minimization of operating and maintenance costs; use of idle mode; transition to part-time work; mobilization of financial and economic resources, etc. However, according to the head of the enterprise A. Yarmak: "cost reduction in the actual absence of revenues could not fully save the situation ... < and for $>$... maintaining liquidity ... in record time (within 4 months) the EBRD's loan financing was attracted on favourable terms for the enterprise" [16]. Thus, the company's management has implemented, in fact, an urgent financial policy - a set of measures to respond promptly and tough to the force majeure loss of economic stability, adequate to the circumstances.

Choosing appropriate methods and tools. Regardless of the chosen type of policy, in compliance with the principles of reliability and consistency, the components of financial policy should be considered in their organic totality and structural unity, which provides the necessary systemic, comprehensive, diverse and alternative solutions and future systems and their subsystems, guaranteeing the overall effectiveness of the political process.

The tasks of financial policy are determined by the needs of financial management of the company and in turn they determine the type of policy, or their consecutive combination. The implementation of measures of a particular type of policy takes place in the framework of the impact on its subsystems using management tools, which are based on:

1. Information and regulatory support - a set of information flows of various kinds, forming an idea of the object of financial management internal and external relations of the enterprise, 
its market position, competitiveness, provision of resources and fixed assets, profitability, capital intensity and return on assets, liquidity, etc., i.e. qualitative and quantitative indicators that characterize the results of its financial and economic activities: financial and management reporting, accounting data, the system of internal reports of structural elements and units, data from State Statistics Committee, media, etc.; The Constitution of Ukraine, laws of Ukraine and international law, presidential decrees, decisions of the Verkhovna Rada, resolutions of the Cabinet of Ministers, letters of ministries and departments, the charter of the business entity, instructions, norms and standards, guidelines, etc.

2. Levers, methods and control tools (corresponding policy types are given in Table 2):

- ways of influencing financial instruments on economic relations: investing, lending, self-lending, self-financing, insurance, rent, leasing, factoring, securitization, fundraising, relationships with founders, etc. business entities, public administration bodies, system of settlements, material incentives and fines, debt, mortgage, trust, transfer operations, etc.;

- means and methods of implementing financial policy objectives: profit, income, price, depreciation deductions, investments, economic trust funds, preferences, discounts, deposits and unit contributions, interest rates, exchange rate quotes, futures and forwards, forms of payment, financial sanctions, insurance policies, etc.

Table 2

Tools for implementing the financial policy of the enterprise (built by authors)

\begin{tabular}{ccc}
\hline Financial management task & The main subsystem of financial policy & Implementation through/with \\
\hline $\begin{array}{c}\text { Ensuring normal operating conditions for } \\
\text { the enterprise. Optimization of money } \\
\text { circulation and support of solvency }\end{array}$ & $\begin{array}{c}\text { Operating, investment, credit, dividend, } \\
\text { accounting, fiscal }\end{array}$ & Enterprise cash flow management \\
$\begin{array}{ccc}\text { Achievements and maintaining financial } \\
\text { stability }\end{array}$ & Operating, investment, accounting & $\begin{array}{c}\text { Budgeting, rationalization of receivables } \\
\text { management, depreciation policy; } \\
\text { pricing policy, etc. }\end{array}$ \\
Profit maximization & Credit, operating, dividend & Acceleration of payment turnover; \\
venture investment; leasing; factoring; & expansion of assortment policy \\
Financial risks minimization & Accounting, investment, credit, fiscal & $\begin{array}{c}\text { Factoring; securitization, hedging; } \\
\text { insurance; debt restructuring, etc. }\end{array}$
\end{tabular}

Depending on the type of financial and economic relations, type of activity and areas of managerial influence, as well as, in accordance with the tasks of financial management, the financial policy of the enterprise is divided into the following subsystems:

- operating policy concerns management decisions in the field of the main activity of the enterprise and determines how and to what extent the enterprise generates cash to ensure the normal rhythm of its economic activities: repayment of loans, maintenance of the appropriate level of production, payment of dividends, new investments from own sources of financing in the process of the main activity and is a process of managing cash inflows from sales of goods (works, services), royalties, royalties, commissions, etc.; payments of funds to suppliers of goods (works, services), employees and payments on their behalf; receipts and payments of money of the insurance company for premiums and claims, annuities, other types of insurance assistance; cash payments or income tax compensation, etc. As part of the company's operating policy, the development of depreciation and pricing policies is being carried out;

- investment policy determines the structure and amount of funds, spent on resources to generate future profits. The elements, targeted by this policy are: costs, associated with the acquisition of property, plant and equipment, intangible assets and other non-current assets; expenses, related to the acquisition of equity or debt instruments of other enterprises, or income from their sale, purchase or sale of shares in joint ventures; advances and cash loans, granted to others. In general - the receipt and expenditure of funds that serve the real and financial investment; 
- credit policy of the enterprise is manifested in terms of operations, related to raising capital, and consists of cash inflows from the issuance of shares and other equity instruments, unsecured debt, loans, promissory notes, bonds, mortgages, etc.; payment of cash to owners for the purchase or redemption of previously issued shares, repayment of loans, reduction of arrears, related to financial leases, other operations, related to attracting external sources of financing;

- accounting policy (according to Article 1 of the Law of Ukraine "On Accounting and Financial Reporting in Ukraine") - a set of principles, methods and procedures, used by the enterprise for the preparation and submission of financial statements [17]; (in accordance with IAS 8) the specific principles, bases, arrangements, rules and practices, applied by an entity in preparing and presenting financial statements. According to the current legislation, the company independently determines its accounting policy in agreement with the owner (owners) or his/her authorized body (official) in accordance with the constituent documents [18]. The correct choice of accounting policy can significantly affect the financial security of the enterprise. The result of Toshiba's controversial accounting policy, which cost the company $\$ 1.2$ billion net losses, is mentioned by us previously in Table 1;

- dividend policy relates to management decisions to optimize the distribution of profits in terms of their spending and capitalization. This policy, in particular, is a tool to influence the market capitalization of the company and is determined by a number of factors: the general economic condition of the enterprise; liquidity; the need to finance the deficit/elimination of the excess cash flow; the need for financial support for innovation, renewal of fixed assets, expansion of production capacity, etc.; peculiarity of accrual of taxes on dividends, etc. The opposition of two driving needs: investors - in obtaining the maximum benefit and corporate management - in maximizing profits in future periods through reinvestment becomes the cornerstone in the formation of optimal dividend policy;

- fiscal policy determines the relationship of the enterprise with the state in terms of the chosen system of taxation. The development of such a policy becomes especially relevant in the conditions of imperfection, instability and opacity of tax legislation, unfortunately, inherent in the domestic realities of doing business. The main task of fiscal policy is to develop and maintain a system of tax accounting in order to implement tax planning, which, in turn, solves the problem of achieving and maintaining optimal levels of liquidity, solvency, financial stability; profit maximization, etc. The effectiveness of this policy is determined by the level of tax optimization in accordance with the strategic and urgent needs of the company in strict compliance with tax laws.

Substantiation of financial policy subsystems is not intended to single out any of them or give it the status of the main, or most significant, but rather to ensure knowledge and transformation of the object of financial management in structural system unity and facilitate the management process in its complex essence.

\section{Conclusions}

Choosing the right type of a financial policy according to given current needs of financial management is crucial and it results either in its efficiency increase (in case of a successful choice) or arousal of economic threats for the company (due to contradictory one). The current research had proven, that company's experience, history of success, size, general life span, brand recognition and so forth do not form "magical protection shield" that eliminates results of ignorant mismanagement. Again, choosing the type of policy does not mean its long-term relevance, but rather, it is advisable to plan their consecutive combinations, taking into account the company's life span and its needs in different perspectives.

Therefore, thorough further research is needed to lay the theoretical and methodological foundations in order build an efficient mechanism of implementing the enterprise financial policy.

\section{References}

[1] Polova, O. L. (2020). Enterprise financial policy. Norwegian Journal of development of the International Science, 42 (3), $28-34$.

[2] Chaikovska, V. P. (2013). Finansova polityka: pidkhody do rozuminnia ta znachennia v diialnosti pidpryiemstva. Naukovi zapysky Natsionalnoho universytetu Ostrozka akademiia. Ekonomika, (23), 247-251. 
[3] Parfeniuk, M. V., Derhaliuk, B. V. (2017). Ekonomichna sutnist poniattia «finansova polityka» ta pryntsypy yii realizatsii na pidpryiemstvi. Efektyvna ekonomika, 5. Available at: http://www.economy.nayka.com.ua/?op=1\&z=5574

[4] Mohammed, Z. O., Al Ani, M. K. (2020). The Effect of Intangible Assets, Financial Performance and Financial Policies on the Firm Value: Evidence from Omani Industrial Sector. Contemporary Economics, 14 (3), 379-391. doi: http://doi.org/10.5709/ ce.1897-9254.411

[5] Niu, W.-N., Wu, W.-X., Ling, L., Zhou, R.-X. (2018). Corporate Financial Policies under Heterogeneous Beliefs. Journal of Management Science and Engineering, 3 (2), 101-124. doi: http://doi.org/10.3724/sp.j.1383.302006

[6] Baum, C. F., Chakraborty, A., Liu, B. (2016). Corporate financial policy and the value of cash under uncertainty. Boston College Working Papers in Economics. Available at: https://ideas.repec.org/p/boc/bocoec/918.html

[7] Dittmar, A., Duchin, R. (2016). Looking in the rearview mirror: The effect of managers' professional experience on corporate financial policy. The Review of Financial Studies, 29 (3), 565-602. doi: http://doi.org/10.1093/rfs/hhv051

[8] Jajuga, K., Orlowski, L. T., Staehr, K. (2017). Contemporary Trends and Challenges in Finance. Springer. doi: http://doi.org/ 10.1007/978-3-319-54885-2

[9] Yereshko, Yu. O. (2011). Upravlinnia hroshovymy potokamy pidpryiemstva. Kyiv, 274.

[10] Yereshko, J., Tovmasian, V. (2020). Theory of enterprise financial policy. Investytsiyi: Praktyka Ta Dosvid, 15-16, 63-68. doi: http://doi.org/10.32702/2306-6814.2020.15-16.63

[11] Holmes, A. (2019) The 13 biggest tech company failures in the last 10 years. Available at: https://www.businessinsider.com/ tech-companies-that-shut-down-went-bankrupt-in-last-decade-2019-11\#2016-pebble-7

[12] Aaslaid, K. (2019). 50 examples of corporations that failed to innovate. Available at: https://www.valuer.ai/blog/50-examplesof-corporations-that-failed-to-innovate-and-missed-their-chance

[13] Kodak: istoriia pro huchni uspikhy ta nevdachi. Available at: https://buduysvoe.com/publications/kodak-istoriya-pro-guchni-uspihy-ta-nevdachi

[14] Surowiecki, J. (2013). Where Nokia went wrong. Available at: https://www.newyorker.com/business/currency/where-nokiawent-wrong

[15] Eurocontrol (2020) Eurocontrol draft traffic scenarios. Available at: https://www.eurocontrol.int/publication/eurocontrol-draft-traffic-scenarios

[16] Makarenko, I. (2020). Yak ,zletity” u skladni chasy. Available at: https://www.unn.com.ua/uk/publication/1891141-yak-zletiti-u-skladni-chasi-kerivnik-ukraerorukhu-rozpoviv-pro-vikliki-ta-antikriz-u-nebi?fbclid=IwAR14pqNZx4GDh_-CVtCpGIxEwT3pTIt56wvw6LfJ-pDdmkuRfQMYj-qZ-A4

[17] Pro bukhhalterskyi oblik ta finansovu zvitnist v Ukraini (1999). Zakon Ukrainy No. 996. 16.07.1999. Available at: https:// zakon.rada.gov.ua/laws/show/996-14\#Text

[18] Oblikova polityka pidpryiemstva. Available at: https://www.buhoblik.org.ua/uchet/organizacziya-buxgalterskogo-ucheta/ 2710-oblikova-politika.html

Received date 17.08.2020

Accepted date 22.09.2020

Published date 30.09.2020
(C) The Author(s) 2020

This is an open access article under the CC BY license (http://creativecommons.org/licenses/by/4.0). 